\title{
The 1915 German-Estonian Phrasebook as an Interface of German- Estonian Language Contact and a Vehicle for Annexationist Propaganda
}

Mart Kuldkepp

The purpose of this chapter ${ }^{1}$ is to consider the ways in which the 1915 German-Estonian phrasebook (subsequently republished in 1916 and 1918), attempted to facilitate German-Estonian language contact while also functioning as a vehicle for German annexationist propaganda. I will argue that by trying to convince its German-speaking audience of the natural 'Germanness' of Estonia and the Estonians in a political and cultural sense, the phrasebook made a contribution towards preparing the ground for a future German occupation of the northernmost part of the Baltic region, meant to be followed by a permanent annexation of the Estonian-speaking areas to Germany. The phrasebook's practical purpose as a language guide must have been limited, not least because the actual occupation of Estonianspeaking areas was delayed until the autumn and winter of 1917-1918. This, however, did not stop the phrasebook from being printed in tens of thousands of copies already before any German troops managed to reach Estonia.

This short study hopes to add a new facet to the growing body of research on dictionaries, phrasebooks and primers as by-products or even tools of war, ${ }^{2}$ while also contributing towards a better understanding of German occupation and annexation policy on the Eastern front - particularly relating to how it was shaped by Baltic German propaganda.

\section{Phrasebooks as linguistic auxiliaries of war-making}

The following discussion will be mostly limited to the 1915 German-Estonian phrasebook, but this does not mean that similar publications were not produced for other target audiences and by other belligerent powers, or that their production and use was particular only to the First World War. Indeed, there are significant similarities with other comparable cases, analyses of which have unveiled racist or colonialist agendas, clearly demarcating between the more and less 'civilised' halves of the language pair. ${ }^{3}$ At least for comparative purposes, it is useful to consider German annexationism also as a form of colonialism, even if it was expected to be realised first and foremost through military occupation, with other measures (such as economic coercion and industrial restructuring benefitting the motherland) following later. This means that insights gathered e. g. from analysis of modern Lonely Planet phrasebooks ${ }^{4}$ are still broadly relevant for the current case study.

The role and provenance of what might be called 'occupation dictionaries,' 'war phrasebooks' and so on is well-documented in recent research. Most helpfully, Simon Constantine has conducted two thorough studies of such materials as used in the First World War, ${ }^{5}$ highlighting both the wide variety available and their impressive print-runs (often in the hundreds of thousands). ${ }^{6} \mathrm{He}$ also points out that most such 
publications were not produced or even commissioned by government officials, but rather appeared on the initiative of private publishers looking to cash in on the enormous market that had opened through mass mobilisation of overwhelmingly literate armies. Whole armies of soldiers were gifted these books, purchased them before being deployed, or did so later in field bookshops. In Germany, military authorities sometimes also bought such publications in bulk and took care of the distribution themselves. ${ }^{7}$

At least in Germany, such books could also be commissioned by the authorities (see e.g. the GermanLithuanian phrasebook, mentioned below), or even produced in-house. An example of the latter is the seven-language dictionary of German, Polish, Russian, Belorussian, Lithuanian, Latvian and Yiddish, which was published in early 1918 by the translation unit of the Supreme Commander of German Forces in the East (Oberbefeh/shaber Ost or Ober-Ost) on the basis of a card catalogue that had been compiled for the purposes of translating official decrees and regulations. The compilers note that as a result, their book includes many expressions that might 'sound barbaric to a philologist,' but nevertheless fulfil a practical purpose. In any case, the fundamental reason for the book's unevenness is explained to lie in the various languages' different stages of cultural development, both in comparison with each other and with German. ${ }^{8}$ Thanks to such institutional and ideological framing, even a dictionary could acquire a distinctly colonialist flavour.

However, while dictionaries could be expected to have fulfilled a primarily practical purpose, Constantine argues that phrasebooks, for the most part, should not be viewed as guides to actual communication. This was partially because their authors often failed to foresee the actual circumstances of their use, with the books rather providing a 'source for the exaggerated expectations on both sides early in the war,' and partially because most verbal exchanges would in any case not be sufficiently patterned to enable straightforward usage, with the possible exception of entirely ritualistic interactions, such as pro-forma interrogations of enemy prisoners. ${ }^{9}$

The actual importance of phrasebooks, Constantine argues, rather lies in the manner in which 'they helped to transmit to soldiers expected norms of conduct for the engagement with civilian populations.' He goes as far as to suggest that 'for German soldiers, the scenarios and dialogue of phrasebooks functioned as a kind of virtual-training, promoting the use of illegal methods of warfare in occupied Belgium and France. ${ }^{\prime 10}$ These insights can be taken as the point of departure also for this inquiry about the expected norms governing German-Estonian relations. Furthermore, if, as argued by Kathleen Sheldon, 'phrase books offer a window into the worldview of those who compile them, and might provide clues about society at large as well, ${ }^{11}$ they can be assumed to say something about the aims of wartime propaganda, reflected in the paratexts attached to the phrasebook, but also in what the imaginary participants say and do in the depicted interactions, and in what sort of exchanges are expected to arise in the first place.

\section{Estonians, Baltic Germans and Germany}

Amongst other German-occupied territories in the First World War, the Baltic provinces (now Estonia and Latvia) were in some ways a unique case. Even though they had formed a part of the Russian Empire from 1721 onwards, they had for centuries both before and after been dominated by a German- 
speaking landed nobility, which traced its roots back to the crusading knights that had conquered these pagan lands back in the $13^{\text {th }}$ century. Having secured a foothold in the Baltics and reduced the native Estonian- and Latvian-speaking populations to serfdom, they managed to maintain their privileges and a broad regional autonomy under the various states that went on to rule over the Baltics from the Middle Ages onwards. ${ }^{12}$

One result of the near-overlap of linguistic and social boundaries in the Baltic provinces was that the Estonian national awakening, beginning around the mid-19 $19^{\text {th }}$ century, found in the Baltic Germans (less than $5 \%$ of the total population) a natural target for both their national and social grievances. This gave the Estonian nationalist movement a strong inner cohesion, helped by the fact that the Baltic German leadership found it impossible to reach a political compromise even with the most moderate Estonian politicians. For a small community deathly afraid of any developments that could have led to their downfall from the status of the privileged elite to that of a disadvantaged national minority, the Estonian nationalist aspirations of putting the provincial system of governance on a more democratic grounding would have been acceptable only if there had been a simultaneous increase in the number and influence of German-speakers - for example through immigration from Germany or from other German-speaking communities in Russia. This, however, was something naturally opposed by even the most conservative Estonians. ${ }^{13}$

Among other consequences, this state of tense inter-ethnic relations made the language question in the Baltic provinces a sensitive one, closely linking the use of German language to the Baltic German claim of cultural and political supremacy in these 'ancient German territories.' Conversely, the prospects of further spreading the use of German on the expense of Estonian and Latvian came to be seen by the Baltic German leadership as something on which the ultimate survival of the Baltic provinces' 'Germanness' depended - either in conjunction with colonisation by German-speaking settlers, or as a possible alternative to it. ${ }^{14}$

The beginning of the First World War sparked in Russia a wave of Germanophobia, directed not only against Germany, but also against Russia's own German-speaking population. The public persecution of Germans was welcomed many Estonians, and certainly contributed to the willingness of conscripted Estonian soldiers and officers to fight for Russia. For example, Juhan Tõrvand, the future chief of staff of the army of the independent Republic of Estonia, wrote in his diary on 22 April 1915: 'These [Germans] can't save themselves! And that's how it should be! Compared to the Russians, I as an Estonian feel the joy of victory over the Teutons a thousand times more. We have sucked in the feelings of historical hate against the Germans already with our mothers' milk. And this hate will only find satisfaction when the German might is destroyed.'15

The wartime German military and political leadership, for their part, was far from unanimous on the question of what to think of Russia's Baltic borderlands. The influential circles in Berlin that supported the conclusion of separate peace between Russia and Germany found it inexpedient to stake such claims on Russian territory, hurting Russian national pride and making the achievement of separate peace more difficult. At the same time, the more uncompromising German annexationists, especially the generals of the Supreme Army Command (Oberste Heeresleitung, $\mathrm{OHL}$ ) who gained the upper hand in the latter part of the war, found in the Baltic provinces a natural target for German expansionism in the East. $^{16}$ 
In this, they were significantly encouraged and aided by exile Baltic German propagandists in Germany. Soon after the beginning of the war, these men had taken up agitation for the conquest and annexation of the whole of the Baltic region by Germany. Well-connected and able to evoke feelings of German national pride by referring to its 'cultural mission in the East', they eventually gained significant influence over German policy. ${ }^{17}$

The initial Baltic German efforts to lobby the German authorities soon led to the establishment of permanent organisations. The first of these, German People's Defence (Deutscher Volksschutz), which had the comparatively modest purpose of defending German economic and political interests in Finland and the Baltic States, was founded already in $1914 .{ }^{18}$ Of course, as long as the relevant territories remained unoccupied by Germany, there was no land available to colonise or Estonians and Latvians to Germanise. Nevertheless, the conquest of Courland by German troops in April 1915 meant that the region came to attract more attention and Baltic German propaganda won a broader audience in Germany.

\section{The Guide Through Livonia, Estonia and Courland with Phrasebooks and a Map}

In May 1915, this new attention accorded to the Baltics led to the founding of a new and more ambitious Baltic German exile organisation, The Confidential Baltic Council (Baltischer Vertrauensrat). It was centred around the figures of Otto von Veh, the head of Vertrauensrat, and its ideological leader Theodor Schiemann, previously the town archivist of Tallinn and later professor of Eastern European history at Berlin University, who acted as a close foreign policy advisor to Wilhelm II. During the 1918 German occupation of Estonia, Schiemann also briefly became the curator of the University of Tartu. ${ }^{19}$

In their first Denkschrift published already before the organisation had been formally founded, Veh and Schiemann stated the following in no unequivocal terms: 'The culture of the Baltic Sea provinces is German [...] still today. The culture of the Estonians and Latvians is also German. They owe it to the Germans. [...] The three provinces constitute a single cultural area and therefore belong together. They have the same faith, the same language of culture (German), the same constitution with local differences. The circumstance that the Estonians live in the north and the Latvians in the south plays no role, as both peoples have only one culture: the German culture. ${ }^{20}$

Vertrauensrat's confidential statement of aims, formulated at its founding on 10 May 1915, furthermore explicitly stated that the purpose of the organisation was to achieve the reunification of the Baltic provinces with Germany and to do all that is necessary to achieve that goal. ${ }^{21}$ The organisation envisioned future Baltic provinces as '[a] great German protestant land with blooming agriculture that is capable of further development, so that it can richly provide Germany with its surplus food production; an area of settlement that can receive Germany's surplus population or German colonists in the millions [...] a population that readily, and, in part, enthusiastically, will acquiesce to German dominance and has already for centuries been used to autonomy built after the German example; a healthy race that will provide able conscripts for the army and the navy. ${ }^{22}$

In addition Vertrauensrat's journal Stimmen aus dem Osten, which quickly became an important vehicle for annexationist propaganda, ${ }^{23}$ and the confidential printed memoranda that were distributed to prominent personalities in German political, military and academic circles, one of the first publications 
produced by Vertrauensrat was a book titled 'Guide Through Estonia, Livonia and Courland. With German-Latvian and German-Estonian 'Phrase Books' and a Map (Führer durch Est-, Liv- und Kurland. Mit deutsch-lettischem und deutsch-estnischem "Sprachführer" und einer Karte). According to a note included in the first edition of the book, it had been published under the aegis of Vertrauensrat by August Löwis of Menar, ${ }^{24}$ one of the two editors of Stimmen aus dem Osten.

It is not entirely clear whether the initiative for this publication came from Vertrauensrat itself or whether it had in some sense been commissioned by the German authorities. The latter possibility is supported by the fact that the compilation of a similar German-Lithuanian phrase book had been initiated in 1914 by the Generalkommando of the I Army Corps, which commissioned one Rittmeister Wilhelm Steputat to undertake the task. ${ }^{25}$ If the same was the case with Vertrauensrat's phrasebook, this would be an interesting addition to the history of German policy development, since the publication of a German-Estonian phrasebook already in 1915, if officially sanctioned, would indicate preparations for an occupation of Estonia already in the early stages of the war - long before the actual occupation in 1917-1918.

However, even if not outright commissioned by the military authorities, the book certainly was distributed by them. According to Veh's letter to other Vertrauensrat members from October 1915, the entire initial print run of 6000 copies had been handed over to the Prussian Ministry of War and the Imperial Naval Office, which intended to bring 5000 copies to the front. ${ }^{26}$ In a report written probably in the following spring, it was furthermore mentioned that the publication, which had 'aroused a lively interest in military circles,' had by that point been printed altogether in 35000 copies in three print runs. $^{27}$

\section{The contents of the phrasebook}

Whatever the degree of the military authorities' exact involvement in the book project, it is clear that as far as Vertrauensrat was concerned, the substance of the publication was in line with its aim of facilitating future German occupation of the whole of the Baltic region. As noted in the general foreword, the book was meant for 'our troops fighting hard in the north-east on land and on sea who would bring the book from Courland to Tallinn and Narva, but would be a trustworthy guide also for everyone else interested in learning about the "oldest colonies of the German Reich."' ${ }^{28}$ Furthermore, the introduction to the phrasebook section states that the phrasebook is meant to facilitate mutual understanding between the readers and the non-German population of the Baltic provinces, containing not just expressions and sentences immediately relevant for military purposes, but also such that would be used 'only in unforced, peaceful conversation. ${ }^{29}$

Before the phrasebook itself, the volume includes a thorough historical overview (narrated, of course, from an entirely Baltic German point of view), a multifaceted description of the region covering geographical, political and cultural aspects, characterisations of the different national groups (Baltic Germans, Latvians and Estonians) and two Baltic German poems full of longing for Germany. ${ }^{30}$ These earlier sections also give a somewhat paranoid framing to the phrasebook proper by urging the German invaders, if possible, to rely on the Baltic German population, whose mindset is described as thoroughly German-national (deutschnational). The Latvians and Estonians are also said to be longing for liberation 
from the Russian yoke, but the reader is warned that unlike the Germans, some of them might be spies. ${ }^{31}$ In the later editions, this warning was dropped, perhaps to not to undermine the central narrative that the Latvians and Estonians were already culturally German.

In terms of general principles of communication, the reader is advised that Latvians can be easily dealt with if one employs correct ('strict but human') methods, i.e. more is achievable by patience and clarification than by sheer threats. In the case of Estonians as well, it was suggested that too strict, curt and sharp treatment was to be avoided as much as possible. ${ }^{32}$ Such paternalism towards one's prospective conversation partners can be compared with Sheldon's observations about Mozambican phrase books, where 'Africans were perceived as potential converts who were equals before God and at the same time [...] continued to hold "pagan" beliefs and practice "uncivilized" customs. ${ }^{33}$ The Latvians and Estonians, likewise, are depicted as potential converts to full 'Germanness', but nevertheless in need of some guidance before they would be able to get there.

The bulk of the book consists of functionally identical introductions to Latvian and Estonian grammar, and German-Latvian and German-Estonian phrasebooks with their lists of words, phrases and dialogues. Finally, the book includes a list of conversion tables between German and Russian weights and measures, and a map of the region. ${ }^{34}$

The phrasebook proper includes lists of words for numbers, time determinants, various adjectives, prepositions, verbs and adjectives, words for people, animals and plants, as well as vocabulary relating to army and navy. ${ }^{35}$ While all this could be regarded as more or less neutral information, more loaded expressions pop up in the section about buying and selling, where phrases are worded as commands rather than requests ('I want to buy this!'). Even more remarkably, the section on 'general expressions' includes such supposedly everyday phrases as 'tell me what you have seen!', 'quiet!', 'idiot!' and 'answer me!,' making it clear what the nature of the exchanges with Estonian-speaking civilians was expected to be. ${ }^{36}$ More expressions that would be useful for ordering people around can also be found in the sections on food and eating ('I want to eat!', 'Make me a soup!'), on 'clothes and equipment' ('Brush my coat!', 'Clean my boots!') and on 'population,' which includes sentences such as 'the corn has to be delivered by tonight!', 'if you do not comply, you will need to pay 100 roubles in fines!', and the ever-useful 'you must follow the orders!' ${ }^{37}$

The section 'in accommodation' is similarly rife with commands, but also includes questions related to intelligence gathering ('how many people are there in this village?', 'where does the pastor live?'). ${ }^{38}$ The same holds true about the next sections 'on the move' ('give me a guide who knows the surroundings well!', 'how long is it to the nearest house, village, manor house?') and 'in the battle.' The latter section is again very much focused on questioning ('where are the enemies?', 'are there Russians on the top of this hill?'), but also includes commands ('hands up!', 'lay down all weapons!') and certain performative utterances ('you are my prisoner!'). ${ }^{39}$ As Constantine points out, sentences like these are found in most German phrasebooks, with nearly all authors anticipating the need to question civilians and issue threats - that in spite of Germany's own commitments under the international law prohibiting such actions. ${ }^{40}$ In any case, the selection of phrases is fully in line with the likely expected needs of 'our troops, fighting hard from Courland to Tallinn and Narva.'

The predominance of imperative forms can also be compared to other similar examples more broadly, such as these founds in the 1944 phrasebook for Allied occupation troops in Germany, about which Hilary Footitt and Michael Kelly note that '[t]roops were clearly expected to be meeting German civilians 
only to give them harsh and explicit orders' or the 1946 Portuguese-Mozambique phrasebook, about which Sheldon points out that ' $[\mathrm{t}]$ he vast majority of the phrases are presented in the imperative verb form, rarely offering any of the polite versions. ${ }^{41}$ Perhaps not unexpectedly, the contents of the 1915 Estonian-German phrasebook therefore mostly fail to bear out the stated purpose of facilitating 'unenforced, peaceful conversation,' or to follow its own recommendation against using threats and acrimonious speech.

In terms of politeness, there is also disparity of expression between the two languages, with the German phrases appearing consistently more polite than their Estonian equivalents. To some extent, this could be due to lack of language skills (the Estonian used in the book is rife with grammatical errors), but it would not be far-fetched to interpret this as colonialist prejudice requiring one to be more straightforward in Estonian whereas more 'civilised' wording would be employed in German. For example, the threat 'if you do not follow my commands, or give me false information, or attempt to betray us, I will immediately make use of my weapons!' (word-by-word from German) is rendered as 'if you do not do what I order, you lie or deceive us, you will immediately be shot!' in Estonian. ${ }^{42}$

\section{The impact and the aftermath}

As stated in the foreword and suggested by its distribution channels, the book was above all intended for military use, but at least this far I have failed to find sources that would tell more about its use on the front. However, it certainly did have some propagandistic impact on German civilian audiences. For example, it was praised at a January 1916 meeting of the German Folklore Society (Verein für Volkskunde), where its chairman Max Roediger read out some of the book's verses expressing longing for liberation by Germany. ${ }^{43}$ In 1917, a reviewer remarked that 'when leafing through this book, one is touched by a certain sense of longing for the old German culture lands [...] just as Elsass-Lothringen after 1871, so will Courland after the end of the war become a new, desirable and frequently visited German travel destination. ${ }^{44}$

Baltic German propaganda also found inroads into the higher echelon of German politics. In a Reichstag speech on 5 April 1916, Chancellor Theobald von Bethmann-Hollweg stated that Germany would not allow the people liberated by Germany and its allies to be returned to Russia, 'whether they be Poles, Lithuanians, Balts or Latvians.' The leadership of the Vertrauensrat took this to indicate that the conquest and colonisation of Estonia and Livonia had been adopted as a German war aim. ${ }^{45}$ Possibly in connection with this belief, a second edition of the phrasebook was published in 1916, its foreword stating that the publication had in a short time found many friends and thankful users both on the front and at home. Now, the editors hoped, it would ease the way for the heroic German troops crossing the Düna river (i.e. the river Daugava dividing the southern part of the Baltic region from the northern provinces Livonia and Estonia). ${ }^{46}$

Daugava would not be crossed for a while, but as $\mathrm{OHL}$, headed by generals Paul Hindenburg and Erich Ludendorff, rose to the position of the de facto military dictatorship of Germany in the last two years of the war, the outlooks of Baltic German propaganda rapidly improved. On 23 April 1917, OHL took the principal decision to attempt to conquer at least a part of the rest of the Baltic region, including the Estonian islands, in addition to Lithuania and Courland already under German occupation. ${ }^{47}$ This meant 
that serious political and military weight was now put behind the two-pronged annexationist solution to the Estonian-Latvian question propagated by Vertrauensrat and its sympathisers: mass colonisation with German-speaking settlers and accelerated Germanisation of the native population through propaganda and German-only education.

If anything, the leaders of Vertrauensrat now had to urge for more cautiousness. In yet another secret memorandum from May 1917, they stated once again that Estonia, Livonia and Courland are 'old, German, colonial lands' that had over the course of 700 years been Germanised thanks to the hard work of their Baltic German upper class. Now, however, they argued that it would be politically inexpedient to openly advocate for forceful Germanisation of Estonians and Latvians, since this would provoke the centrist and radical forces that had arisen in German politics. Furthermore, it was advised, forceful Germanisation would not even be necessary, as these small 'splinters of nations' would be unable to withstand the impact of German progress and would in a generation be anyway completely overrun by the settlement of 2 million German-speakers from Russia with their high nativity rates. ${ }^{48}$

In autumn 1917 and winter 1918, the long-awaited German occupation of Livonia and Estonia finally began. The third, 1918 edition of the phrasebook includes a new, jubilant foreword by the editor (dated with 8 September 1917) beginning with the words 'Riga is ours!' and thanking the 8th Army and the German fleet for their new conquests in the Baltics. ${ }^{49}$ The following occupation of the Estonian islands in October 1917 and the invasion of Estonian mainland in February 1918 was possibly the first time that the German-Estonian phrasebook saw actual use as intended, by German soldiers to communicate with Estonian civilians.

However, any such use was probably limited, and it is more than likely that the eventual significance of this publication remained primarily propagandistic. This is also demonstrated by the fact that the Estonian phrases in the 1916 and 1918 editions repeat all the same typos and mistakes already found in the first edition - native Estonian input to correct them was either not forthcoming, or not even sought. Indeed, the only Estonian opinion of this book that I have come across is a critical one: a copy of the 1918 edition in the University of Tartu library bears in its first page an exasperated scribble in Estonian: 'the author of this book is one of the stupidest people ever to be born.'

\section{Conclusions}

The 1915 German-Estonian phrasebook, subsequently republished in two more editions, was a product of Baltischer Vertrauensrat, a Baltic German lobby organisation that was based in Berlin and spreading propaganda with the aim of achieving the occupation and annexation of all three Baltic provinces to Germany. Rather than fulfilling any immediate practical purpose, it seems that the Estonian part of phrasebook was primarily used as a work of propaganda, spreading the notion that the Baltic provinces

- including their non-German majority population - were already culturally German, and should become politically German as well. This process of Germanisation would be further facilitated by occupation, denationalisation of the Latvians and Estonians, and colonisation of their territories with Germanspeaking settlers.

The contents of the phrasebook follow the conventions of other similar German publications of the period, expecting the invading troops to issue threats and commands to the civilian population and to 
interrogate them for the purposes of intelligence gathering, thereby undermining its own narrative about the already basically German culture and sympathies of the Latvians and Estonians. As the time window when the German-Estonian phrasebook could have been used for its intended purpose was rather narrow, its practical application must have been limited. However, in conjunction with other propaganda initiatives of the Baltic German annexationists, it probably did have some impact on the public opinion and policies of the military leadership in Germany, especially during the last two years of the war that saw an annexationist swing in German policy towards the Baltics.

\section{Bibliography}

Archives

Bundesarchiv Berlin-Lichterfelde, R 8054 (Baltischer Vertrauensrat), Vol 2, Otto von Veh, Meine verehrten Landsleute!

Bundesarchiv Berlin-Lichterfelde, R 8054 (Baltischer Vertrauensrat), Vol 9, I Jahresbericht. Entwurf. Politisches Archiv des Auswärtigen Amtes, R 10199. Wilhelm Steputat, Denkschrift über Litauen im Jahre 1914.

\section{Printed Primary Sources}

Brunner, K. (1916). 'Aus den Sitzungs-Protokollen des Vereins für Volkskunde', Zeitschrift des Vereins für Volkskunde, pp. 221-224.

Dehn, P. (1917). 'Mitteilungen. Ein neues Reiseziel in Osteuropa', Osteuropäische Zukunft. Zeitschrift für Deutschlands Aufgaben im Osten und Südosten, No. 17, p. 256.

Führer durch Est-, Liv- und Kurland. Mit deutsch-lettischem und deutsch-estnischem "Sprachführer" und einer Karte, (1915), Oldenburg: Gerhard Stalling, Verlag des Deutschen Offizierblattes.

Führer durch Est-, Liv- und Kurland. Mit deutsch-lettischem und deutsch-estnischem "Sprachführer" und einer Karte. 2. Auflage, (1916), Oldenburg: Gerhard Stalling, Verlag des Deutschen Offizierblattes.

Führer durch Est-, Liv- und Kurland. Mit deutsch-lettischem und deutsch-estnischem „Sprachführer" und einer Karte. 39 Tausend, (1918), Oldenburg: Gerhard Stalling, Verlag des Deutschen Offizierblattes.

Sieben-Sprachen-Wörterbuch. Deutsch/Polnisch/Russisch/Weissrussisch/Litauisch/Lettisch/Jidisch. Herausgeben im Auftrage des Oberbefehlshabers Ost, (1918), Berlin: Presseabteilung des Oberbefehlshabers Ost. 


\section{Secondary Literature}

Constantine, S. (2011), 'War of Words: Bridging the Language Divide in the Great War', War in History, Vol. 18, No. 4, pp. 515-529.

Constantine, S. (2013), '"If an Inhabitant Attacks, Wounds or Kills a Soldier, the Whole Village Will Be Destroyed": Communication and Rehearsal in Soldiers' Phrasebooks 1914-1918', Journal of War \& Culture Studies, Vol. 6, No. 2, pp. 154-168.

Footitt, H. (2010), 'Languages at War: Cultural Preparations for the Liberation of Western Europe', Journal of War \& Culture Studies, Vol. 3, No. 1, pp. 109-121.

Footitt, H. and M. Kelly (2012), Languages at War. Policies and Practices of Language Contacts in Conflict, Basingstoke: Macmillan.

Hallett, R. W. (2017), '"A Taste of This Lively Language": Attitudes Towards Languages Other than English in Lonely Planet Phrasebooks', Journal of Multicultural Discourses, Vol. 12, No. 3, pp. 222-238.

Kruus, H. (1920), Saksa okkupatsioon Eestis. Tartu: Odamehe kirjastus.

Kuldkepp, M. (2015), 'Hegemony and Liberation in World War I: The Plans for New Mare Nostrum Balticum', Ajalooline Ajakiri. The Estonian Historical Journal, No 3, 249-284.

Kuldkepp, M. (2016), 'Rahvusliku enesemääramise kaudu Saksamaa külge: eestlased anneksionistliku Saksa poliitika sihtmärgina 1918. aasta okupatsiooni eel', in Tõnu Tannberg (ed.), Esimene maailmasõda ja Eesti II, Tartu: Eesti Ajalooarhiiv, pp. 369-433.

Kuldkepp, M. (2019), 'Eestlased ja "eestlase vaenlased." Survemeetmed baltisakslaste ja nende poolehoidjate vastu Eesti Vabadussõja ajal', in Tõnu Tannberg (ed.), Vabadussõja mitu palet, Tartu: Rahvusarhiiv, pp. 365-421.

Lehmann, J. (1994), 'Der Baltische Vertrauensrat und die Unabhängigkeit der baltischen Staaten Ausgangs des ersten Weltkriegs', Journal of Baltic Studies, Vol. 25, No. 2, pp. 131-138.

Loit, A. (2006), 'Baltisaksa rüütelkondade seisukohad ja tegevus Eesti iseseisvumisel 1918-1920', Tuna. Ajalookultuuri ajakiri, No. 4, pp. 50-74.

Mann, B. (1965), Die baltischen Länder in der deutschen Kriegszielpublizistik 1914-1918. Tübingen: Mohr. Pajur, A. (2009), 'Landeswehr'i sõja puhkemine. Eesti vaatenurk', Tuna. Ajalookultuuri ajakiri, No. 2, pp. 58-64.

Raun, T. U. (2001), Estonia and the Estonians. Updated Second Edition. Stanford: Hoover Institution Press.

Sheldon, K. (1998), "'Rats Fell from the Ceiling and Pestered Me:" Phrase Books as Sources for Colonial Mozambican History', History in Africa, Vol. 25, pp. 341-360.

Steputat, W. (1915). Litauischer Sprachführer. 2. bis 6. verbess. Aufl. Tilsit: Druck und Verlag Buchdruckerei „Lithuania“. 
Notes

${ }^{1}$ The research for this chapter has been supported by the project PHVAJ16908 'War after War: The War Experience of Estonian Servicemen in the Twentieth Century', funded by University of Tartu.

2 See S. Constantine, 'War of Words: Bridging the Language Divide in the Great War' in War in History, Vol. 18, No. 4, 2011, pp. 515-529; S. Constantine, "'If an Inhabitant Attacks, Wounds or Kills a Soldier, the Whole Village Will Be Destroyed": Communication and Rehearsal in Soldiers' Phrasebooks 1914-1918' in Journal of War \& Culture Studies, Vol. 6, No. 2, 2012, pp. 154-168; H. Footitt, 'Languages at War: Cultural Preparations for the Liberation of Western Europe' in Journal of War \& Culture Studies, Vol. 3, No. 1 2010, pp. 109-121; H. Footitt and M. Kelly, Languages at War. Policies and Practices of Language Contacts in Conflict (Basingstoke: Macmillan, 2012).

${ }^{3}$ See R. W. Hallett, "'A Taste of This Lively Language": Attitudes Towards Languages Other than English in Lonely Planet Phrasebooks' in Journal of Multicultural Discourses, Vol. 12, No. 3, 2017, pp. 222-238; K. Sheldon, "Rats Fell from the Ceiling and Pestered Me:" Phrase Books as Sources for Colonial Mozambican History' in History in Africa, Vol. 25, 1998, pp. 341-360.

${ }^{4}$ Hallett, A Taste of This Lively Language.

${ }^{5}$ Constantine, War of Words; Constantine, If an Inhabitant Attacks.

${ }^{6}$ Constantine, War of Words, p. 516; Constantine, If an inhabitant Attacks, p. 155.

7 Ibid., pp. 155-156.

${ }^{8}$ Sieben-Sprachen-Wörterbuch. Deutsch/Polnisch/Russisch/Weissrussisch/Litauisch/Lettisch/Jidisch. Herausgeben im Auftrage des Oberbefehlshabers Ost (Berlin: Presseabteilung des Oberbefehlshabers Ost, 1918), pp. 5-6.

${ }^{9}$ Constantine, War of Words, pp. 516-518.

${ }^{10}$ Constantine, If an Inhabitant Attacks, pp. 154.

${ }^{11}$ Sheldon, Rats Fell from the Ceiling, p. 341.

12 The best one-volume history of Estonia in English remains T. U. Raun, Estonia and the Estonians. Updated Second Edition (Stanford: Hoover Institution Press, 2001).

${ }^{13}$ See M. Kuldkepp, 'Eestlased ja "eestlase vaenlased." Survemeetmed baltisakslaste ja nende poolehoidjate vastu Eesti Vabadussõja ajal', in Tõnu Tannberg (ed.), Vabadussõja mitu palet (Tartu: Rahvusarhiiv, 2019), pp. 365-421. ${ }^{14}$ See e.g. the memoranda to that effect presented to the German military authorities during the 1918 German occupation of Estonia: H. Kruus, Saksa okkupatsioon Eestis (Tartu: Odamehe kirjastus, 1920), pp. 64-68.

${ }^{15}$ A. Pajur, 'Landeswehr'i sõja puhkemine. Eesti vaatenurk' in Tuna. Ajalookultuuri ajakiri, No. 2, 2009, p. 59.

${ }^{16} \mathrm{M}$. Kuldkepp, 'Hegemony and Liberation in World War I: The Plans for New Mare Nostrum Balticum' in Ajalooline Ajakiri. The Estonian Historical Journal, No 3, 2015, pp. 259-260.

${ }^{17}$ About German colonialism in the Baltics, see B. Mann, Die baltischen Länder in der deutschen Kriegszielpublizistik 1914-1918 (Tübingen: Mohr, 1965).

${ }^{18}$ A. Loit, 'Baltisaksa rüütelkondade seisukohad ja tegevus Eesti iseseisvumisel 1918-1920', in Tuna. Ajalookultuuri ajakiri, No. 4, 2005, p. 53

$19 \mathrm{lbid}$.

${ }^{20}$ Quoted in J. Lehmann, 'Der Baltische Vertrauensrat und die Unabhängigkeit der baltischen Staaten Ausgangs des ersten Weltkriegs' in Journal of Baltic Studies, Vol. 25, No. 2, 1994, p. 131.

${ }^{21} \mathrm{lbid}$.

${ }^{22}$ Quoted in Lehmann, Der Baltische Vertrauensrat, p. 132.

${ }^{23}$ Loit, Baltisaksa rüütelkondade seisukohad, p. 53.

${ }^{24}$ Führer durch Est-, Liv- und Kurland. Mit deutsch-lettischem und deutsch-estnischem "Sprachführer" und einer Karte (Oldenburg: Gerhard Stalling, Verlag des Deutschen Offizierblattes, 1915), no page number.

${ }^{25}$ Politisches Archiv des Auswärtigen Amtes, R 1099, Wilhelm Steputat, Denkschrift über Litauen im Jahre 1914, p.

33. Steputat's German-Lithuanian phrase book went on to be published in a number of editions: W. Steputat, 
Litauischer Sprachführer. 2. bis 6. verbess. Aufl. (Tilsit: Druck und Verlag Buchdruckerei „Lithuania“, 1915). I would like to thank Vasilijus Safronovas for his help with establishing the identity of the author of this Denkschrift.

${ }^{26}$ Bundesarchiv Berlin-Lichterfelde, R 8054 vol 2, Otto von Veh, Meine verehrten Landsleute!, p. 60. 23.11.1915.

27 Bundesarchiv Berlin-Lichterfelde, R 8054 vol 9, I Jahresbericht. Entwurf, p. 247.

${ }^{28}$ Führer durch Est-, Liv- und Kurland, p. 1.

29 Ibid., p. 39.

${ }^{30}$ For the various sections, see, respectively, Ibid., pp. 3-12, 13-19, 19-36, 37-38.

${ }^{31}$ Ibid., pp. 12-14.

32 Ibid., pp. 17-18.

${ }^{33}$ Sheldon, Rats Fell from the Ceiling, p. 346.

${ }^{34}$ Führer durch Est-, Liv- und Kurland, pp. 39-83; 85-87.

35 Ibid., pp. 65-71, 79-81.

36 Ibid., pp. 65-66, 69-70.

37 Ibid., pp. 71-72, 75.

${ }^{38}$ Ibid., pp. 76.

39 Ibid., pp 77-78, 81-82.

${ }^{40}$ Constantine, If an Inhabitant Attacks, p. 161, 163.

${ }^{41}$ Footitt, Kelly, Languages at War, p. 79; Rats Fell from the Ceiling, p. 344.

42 Führer durch Est-, Liv- und Kurland, p. 83.

${ }^{43} \mathrm{~K}$. Brunner, 'Aus den Sitzungs-Protokollen des Vereins für Volkskunde' in Zeitschrift des Vereins für Volkskunde, 1916, p. 221.

${ }^{44}$ P. Dehn, 'Mitteilungen. Ein neues Reiseziel in Osteuropa' in Osteuropäische Zukunft. Zeitschrift für Deutschlands Aufgaben im Osten und Südosten, No. 17, 1917, pp. 256.

${ }^{45}$ Lehmann, Der Baltische Vertrauensrat, pp. 132-133.

${ }^{46}$ Führer durch Est-, Liv- und Kurland. Mit deutsch-lettischem und deutsch-estnischem „Sprachführer" und einer Karte. 2. Auflage (Oldenburg: Gerhard Stalling, Verlag des Deutschen Offizierblattes, 1916), p. 2.

${ }^{47}$ M. Kuldkepp, 'Rahvusliku enesemääramise kaudu Saksamaa külge: eestlased anneksionistliku Saksa poliitika sihtmärgina 1918. aasta okupatsiooni eel', in Tõnu Tannberg (ed.), Esimene maailmasõda ja Eesti II (Tartu: Eesti Ajalooarhiiv, 2016), p. 373.

${ }^{48}$ Lehmann, Der Baltische Vertrauensrat, p. 133.

${ }^{49}$ Führer durch Est-, Liv- und Kurland. Mit deutsch-lettischem und deutsch-estnischem „Sprachführer" und einer Karte. 39 Tausend (Oldenburg: Gerhard Stalling, Verlag des Deutschen Offizierblattes, 1918), p. 37. 